\title{
Leaving Religion: Introducing the Field
}

\author{
Daniel Enstedt, Göran Larsson and Teemu T. Mantsinen
}

In 1968, the New York Times published the sociologist Peter Berger's now famous prediction about the coming decline of religion worldwide. In this context, Berger stated that the remains of religion in the twenty-first century would consist of religious believers "likely to be found only in small sects, huddled together to resist a worldwide secular culture" (Berger 1968: 3). People around the world were, in short, expected to leave religion altogether as their societies became modern. It was not a question about if the change would occur, only a matter of time. More than 30 years later, in 1999, Berger revised his earlier claim and instead declared the world as desecularised (Berger 1999). He is, however, far from alone in criticising, or even dismissing, the century old secularisation thesis, where modernisation of a society goes hand in hand with secularisation. ${ }^{1}$ Even though leaving religion - that is the focus in this handbook - has, from time to time, been associated with irreligiosity, agnosticism, and atheism, and, in particular, modernised Western predominantly Christian countries, it can very well also be about leaving one religion from another, or even changing position within the same religious tradition, for example when orthod ox Chassidic Jews becoming reformed, liberal Jews (see, for instance, Davidman 2015).

In 2015, PEW Research Center published the report The Future of World Religions, where the overall global tendencies, at least until 2050, are about growth of religion. Around the world, religious population is increasing according to the prediction - the Muslim population will grow significantly, and in 2070 Islam will be at the same size as Christianity, that is around one third of the world population - and only a small percentage of the world's population are expected to be disaffiliated or non-religious. Leaving out a critical discussion about the accuracy of this study and its methodological problems, one of the factors analysed in the statistically based projection was "religious switching,"

1 See for instance Toft, Philpott and Shah, God's Century. Resurgent Religion and Global Politics (2011). Before Berger's 1999 article many scholars in religious studies has contested the secularisation thesis, even though the secularisation thesis was generally accepted in the social sciences and in the public debate, not the least in Western Europe. 
that is religious change on an individual level. Even though religious switching has "a relatively small impact on the projected size of major religious groups in 2050" (PEW Research Center 2015:45), it may have an effect on different regions around the globe. Mobility between religions and non-religion is also related to various regions and global processes, such as, for example migration flows. That means that even though many people will be switching in, out and between religions up until 2050, the total number of religious adherents around the world will not be affected in a significant way. Switching out of a religion in favour of a non-religious position also seems to be more prevalent in the US and Europe than other parts of the world (see also the prognosis made by Stolz et al. 2016). ${ }^{2}$ The decrease of Christian population in the Western countries is also, in part, related to a question of declining role of family in cultural transmission of religion (Need and De Graaf 1996). Social factors are important in both staying in and leaving religion. However, this and other factors, such as, for example, pedophilia scandals in the Catholic church, can also result in leaving religious institutions or declining attendance rather than religiosity in general (Bottan and Perez-Truglia 2015).

However, in more recent times, new theoretical and methodological approaches have emerged and there is a growing interest in deconversion and various forms of leaving religion studies, but still we think that it is difficult to get a comprehensive introduction and overview to these studies. For example, in so-called cult studies, the main definition of leaving religion has been apostasy (Bromley 1998). Other definitions of exits, or people exiting, concentrate usually on describing the exit process or deconversion (Richardson, van der Lans and Derks 1986; Streib et al. 2009). Whilst the term apostasy (Greek: apo stenai - to stand away of something) can be viewed negatively, at least as an invective used by a religious groups or individuals to define a defector (Larsson 2018a), it has also been used in research to characterise people who leave religion and then become a part of the critique directed towards the same religion, or simply be understood as any position outside the religious group of origin. There are, according to John D. Barbour, four basic characteristics of deconversion autobiographies. "Deconversion encompasses," Barbour writes, "intellectual doubt, moral criticism, emotional suffering, and disaffiliation from a community" (Barbour 1994: 2). Not all of these aspects are expressed in every deconversion narrative, and the emphasis can also be put in various ways. On the basis of previous research, Phil Zuckerman stipulate three dimensions of

2 See also PEW's report about so called "Nones," the religious disaffiliated part of the population: http://assets.pewresearch.org/wp-content/uploads/sites/11/2012/10/NonesOnTheRisefull.pdf. Accessed 28/5/2018. 
apostasy, that is "early/late, shallow/deep, mild/transformative [that] manifest themselves in various combinations" (Zuckerman 2012: 8). ${ }^{3}$ In addition, studies on leaving religion have also been examining the motifs and reasons, the processes and consequences of leaving religion.

Although one could argue that the study of leaving religion is a neglected topic in the academic study of religions it is hard to define what "leaving" entails. While the study of conversion is a relatively well researched topic (from James 1902 to various handbooks, such as, for example, Rambo's and Farhadian's The Oxford Handbook of Religious Conversion, 2014), surprisingly few studies have put focus on the fact that conversion implies that the individual moves from or leaves one position - say a Christian identification to another religion - but what the process of leaving entails is often hard to isolate or reduce to one factor. For example, even after a formal divorce a person still holds (good, bad, painful, happy or indifferent) memories of his or her former spouse. It is likely that this observation also holds true for many individuals who have decided to leave a religious belonging or other social formations (for example political parties, gangs, an addictive lifestyle, etcetera). Behaviours rooted in moral codes and religious teachings (especially if they have been adopted at a young age) tend to colour the life of the individual even though he or she has taken a new path. Sometimes the former belonging can be a source of anger and it can provoke a strong need to demonstrate that the earlier life was wrong (see, for example, Larsson 2016). For example, the change to something new can be expressed by the help of a novel vocabulary, but also by putting on "different" clothes (for example the veil, or by growing a beard, or by shaving), adopting new behaviours and to take up another sexual identity. Food, clothing and sexual orientations seems to be strong markers of identity and they are often used for expressing one's attitude towards the society and one's religious belonging. In a sense we are all coloured by our former belongings, identities and experiences, if we are to believe Helen Ebaugh's analysis in Becoming an Ex: The Process of Role Exit (1988).

Since the World War II and the adoption of the Declaration of Human Rights by the United Nations, individuals in most parts of the world have been given the possibility and freedom to change and abandon a religious life. This is stipulated in Article 18:

Everyone has the right to freedom of thought, conscience and religion; this right includes freedom to change his religion or belief, and freedom,

3 There are several different definitions of apostasy in the research literature. See Zuckerman (2012: 4-13) for a brief overview. 
either alone or in community with others and in public or private, to manifest his religion or belief in teaching, practice, worship and observance. ${ }^{4}$

This right is, however, not always respected and to leave a religious life can often be associated with social costs (exclusion), personal grief (the loss of friends and relatives) or even personal risk and threats (see, for example, Larsson 2018a). That so-called apostates - that is those who have actively left a religious tradition by embracing a new religion, or lifestyle, or those who have been accused of apostasy because of their lifestyle, or interpretations of a specific religious tradition - can put themselves in a dangerous position in many countries outside of Europe, North America and Australia is evident (see, for example, International Freedom of Religion Report 2017). That individuals who leave Islam are more likely to suffer from persecutions and threats than individuals who leave many other religious traditions today is well-document and many countries dominated by Muslim traditions are also prone to execute socalled apostates (for example Iran, Sudan and Saudi Arabia) (Larsson 2018a). However, it is inaccurate to argue that the question of leaving religion is only a matter that concerns Islamic traditions and Muslims theologians, on the contrary. As this handbook sets out to explore, the question of leaving a religious tradition is a common question and a potential problem within all religious traditions in both past and present. To draw up a line between insiders and outsiders and to argue that one's interpretation of the religious tradition is right and that one's opponents are wrong (for example by calling the other group heretics, or apostates) is therefore a general pattern that is found in all social formations that make use of a religious vocabulary. This is, for example, the case in the bloody wars in present day Syria and Iraq. Whilst the Islamic State (ISIS) argues that their opponents - may they be Shia Muslims, non-Muslims, atheists or just Sunni Muslims who do not follow or accept the claims made by the Islamic State - are labelled as apostates, the critics argue that it is the followers of the Islamic State who are the evildoers and by their thoughts and actions they "prove" that they are not proper or "true" Muslims (Larsson 2017). The proclivity to make up real or imagined boundaries between insiders and outsiders, or so-called heretics and orthodox, is well-documented in the history of religions. However, in earlier studies these processes and tendencies are rarely studied as part and parcel of conversion, deconversion, leaving religion, and apostasy. The change of a religious orientation is also closely related to the question of who has the power and authority over religious interpretations,

4 Retrieved from http://www.un.org/en/universal-declaration-human-rights/. Accessed 30/ $5 / 2018$. 
and the possibility for the individual to break free from established norms and values.

Whereas the right to change one's attitude towards a specific religious tradition and switch to a new belonging or a novel lifestyle is an individual freedom and legal right in Europe, this is not always the case in non-western countries. Because of political and economic structures (that is weak states that do not provide equal opportunities for all citizens), the possibility of changing one's religious belonging is often closely related to matters such as family, class, gender and tribe. To change religion or to abandon a religious lifestyle could therefore be linked to material and legal aspects and not only philosophical or dogmatic questions. However, over the last decades, the question of freedom of religion has also been put under much pressure in Northern and Western Europe and the right to change religion is often met with critique and strong reactions. This reality is often experienced by individuals who convert to Islam (see, for example, Inge 2017), but also by individuals who leave Islam after they have migrated to Europe and gained a new citizenship. Both those who leave and those who enter a religious tradition are therefore likely to be in a vulnerable position and indications of hate crimes and discrimination are sometimes reported in relation to conversion processes (Främlingsfientliga handlingar 2014; Larsson 2018b). However, the data for these types of crimes are difficult to estimate, and it is likely that these types of crimes are underreported, and that hate and discrimination is more common than we think. This is a topic for future research. While the large majority of individuals who attain a new attitude and lose interest in their former religious tradition, it is also likely that some individuals can join or be used by those who are interested in criticising a specific religious group. Thus, it is not unusual to find former ex-Muslims among those who are strong critiques of Islam (Larsson 2016; Enstedt and Larsson 2013), but former members in so-called religious sects or new religious movements are often recruited by the so-called anti-cult movement (see, for example, Foster 1984; Wright 2014; Wright and Ebaugh 1993). While an individual could have suffered from and experienced physical or psychological violence when they belonged to a specific religious group, it is not hard to understand that an individual also could have good reasons to criticise one's former belonging. For example, in order to make a rational explanation for earlier behaviours and belongings it is also necessary to distance oneself from the ex-position and one way to do so is to publicly frown upon one's former religion. A new identity is constructed also by how a person relates to their past.

As fieldwork and interviews with, for example, ex-Muslims have shown (Enstedt 2018) it is common to seek other ways out from a religious tradition. Losing and gaining new interests and to fade out from a religious life seems to 
be a common way out. Compared to the public critiques this group of exmembers seldom feel that they have a need for criticising their former belonging. For example, as shown by Enstedt (2018), it is clear that many ex-Muslims are still coloured by their former religious identity, not the least when it comes to difficult questions such as drinking alcohol or eating pork. Even after they have distanced themselves from their Islamic identity, they can feel uneasy when they eat pork or drink alcohol after they have embraced a non-Muslim identity. The endurance of some cultural habits is strong especially if they have a positive effect in coping difficult situations, such as joining new groups or facing stress, bringing safe structure in transition. For example, an exPentecostal might start speaking in tongues even when they do not believe in such ritual anymore, when confronted with a stressful situation (Mantsinen 2015).

As this handbook tries to demonstrate it is important to address the obvious fact that theologians (no matter of religious tradition) have never had one single and unanimous understanding of how to define apostasy, orthodoxy or heresy, and this is also often true when it comes to the question of leaving. To put it differently, what does it entail to leave a religion? Should the "heretic" or apostate be defined by his actions or his thoughts, is it necessary to publicly denounce a religious tradition to be looked upon as a defector, or is it enough that a theologian defines an individual as an apostate to make him or her an outsider? Furthermore, how should an apostate, or an individual who leaves a religious tradition, be looked upon by his or her co-religionists and even more importantly, how should he or she be treated? Should such an individual be punished by the believers, or is the punishment up to God? Should the punishment be earthly or is it expected to happen in the next life? Does a change of religion have an impact on the individual's social status and legal rights? For example, what happens if the apostate is married and has children? These and other questions are often related to religious dogmas, but also to practical and legal matters as illustrated in several chapters included in this handbook.

The following handbook on leaving religion consists of three parts covering: (1) Major debates about leaving religion; (2) Case studies and empirical insights; and, finally, (3) Theoretical and methodological approaches. Part 1 in the handbook deals mainly with the so-called World Religions and the aim is to provide the reader with an introduction to key terms, historical developments, major controversies and significant cases within Judaism, Christianity, Islam, Hinduism and Buddhism. Part 2 includes case studies that illustrates 
various processes of leaving religion from different perspectives, and the ambition is that each chapter should provide new empirical insights. The chapters in this part contains a background, an overview to previous research, a description of the available material and the goal is to present new results within this field of study. Contrary to the first part of the handbook, the case studies in Part 2 are contemporary and the large majority are based on original fieldwork. Compared to this part, Part 3 discuss, present and encourage new approaches to the study of leaving religion by bringing in theoretical and methodological viewpoints. Thus, each chapter introduces theoretical and methodological perspectives as well as new findings, and objectives are to suggest how leaving religion can be studied in the future.

To make the handbook as user-friendly as possible we have used the same subheadings for all chapters included in Parts 1 and 3. However, in Part 2 the structure is less fixed and because of this there are some variations in the organisation of the chapters in this part of the handbook. The length of the chapters has been restricted in order to make the book a user-friendly and easy reference tool to use when reading upon the subject of leaving religion or for planning research on this or related topics.

As the readers of the handbook will notice there is a fair amount of research on the questions of apostasy and heresy in Islamic and Christian traditions as well as on leaving various new religious traditions in contemporary times, but similar data for Hinduism and Buddhism and ancient times are generally much more meagre. This should not be read as an indication that these traditions or time periods had no individuals who left or stepped outside of their religious traditions. On the contrary, it rather suggests that researchers have not paid enough interest to traditions like Hinduism and Buddhism or ancient times. A related issue is that scholars of religion often approach their subject through their (Western) cultural lenses, when determining who is religious and affiliated with a religious tradition. This can lead to challenges of detecting and understanding leaving Religion when there is no resignation or clear distinction between social belongings. One overarching goal of the handbook on leaving religion is to remedy this problem of limited scope and as editors we hope that our compilation of texts will stimulate future research, not the least when it comes to other traditions than Christianity and Islam.

\section{References}

Barbour, J.D. 1994. Versions of Deconversion: Autobiography and the Loss of Faith. Charlottesville: University Press of Virginia. 
Berger, P.L. 1968. "A Bleak Outlook is Seen for Religion." New York Times. February.

Berger, P.L. 1999. "The Desecularization of the World: A Global Overview," The Desecularization of the World: Resurgent Religion and World Politics, ed. Peter L. Berger. Grand Rapids: William B. Eerdmans Publishing Company, 1-18.

Bottan, N.L. and Perez-Truglia, R. 2015. "Losing My Religion: The Effects of Religious Scandals on Religious Participation and Charitable Giving." Journal of Public Economics. 129: 106-119.

Bromley, D.G., ed. 1998. The Politics of Religious Apostasy: The Role of Apostates in the Transformation of Religious Movements. Westport, Conn.: Praeger.

Davidman, L. 2015. Becoming Un-orthodox: Stories of Ex-Hasidic Jews. Oxford and New York: Oxford University Press.

Ebaugh, H.R.F. 1988. Becoming an Ex: The Process of Role Exit. Chicago: University of Chicago Press.

Enstedt, D. 2018. "Understanding Religious Apostasy, Disaffiliation and Islam in Contemporary Sweden." In K. van Nieuwkerk, ed., Moving in and Out of Islam, Austin: University of Texas Press, $67-87$.

Enstedt, D. and Larsson, G. 2013. "Telling the Truth about Islam? Apostasy Narratives and Representations of Islam on WikiIslam.net." CyberOrient. 7:1.

Foster, L. 1984. "Career Apostates: Reflections on the Works of Jerald and Sandra Tanner." Dialogue: A Journal of Mormon Thought. 17:2, 35-60.

Inge, A. 2017. The making of a Salafi Muslim woman: paths to conversion. New York, NY: Oxford University Press.

International Freedom of Religion Report. US Department of State. At: https://www .state.gov/j/drl/rls/irf/. Accessed 22/4/2018.

James, W. 1902. The Varieties of Religious Experience: A Study in Human Nature. Longmans, Green, and Co.

Larsson, G. 2016. “'Muslims are Like You and I, but "Real” Muslims...' Ex-Muslims and Anti-Muslim Sentiments." Journal of Muslims in Europe. 5, 205-223.

Larsson, G. 2017. "Apostasy and Counter-narratives - Two Sides of the Same Coin: The Example of the Islamic State." The Review of Faith \& International Affairs, 15:2, 45-54.

Larsson, G. 2018a. "Disputed, Sensitive and Indispensable Topics: The Study of Islam and Apostasy." Method and Theory for the Study of Religions. 30:3, 1-26.

Larsson, G. 2018b. "Let's talk about apostasy! Swedish Imams, Apostasy Debates, and Police Reports on Hate Crimes and (De)conversion." In K. van Nieuwkerk, ed., Moving in and Out of Islam, Austin: University of Texas Press, 385-404.

Mantsinen, T.T. 2015. "Vastustavat uskonnolliset ja ymmärtävät ateistit: Uskonnosta luopujien eri tyypit helluntailaisesta uskonnosta luopuneilla." Uskonnontutkija. 6:1-2.

Need, A. and De Graaf, N.D. 1996. “Losing My Religion': A Dynamic Analysis of Leaving the Church in the Netherlands." European Sociological Review. 12:1, 87-99. 
PEW Research Center. 2012. "Nones" on the Rise: One-in-Five Adults Have No Religious Affiliation At: http://assets.pewresearch.org/wp-content/uploads/sites/11/2012/10/ NonesOnTheRise-full.pdf. Accessed 28/05/2018.

PEW Research Center. 2015. The Future of World Religions: Population Growth Projections, 2010-205o. At: http://assets.pewresearch.org/wp-content/uploads/sites/ 11/2015/03/PF_15.04.02_ProjectionsFullReport.pdf. Accessed 28/5/2018.

Rambo, L.R., and Farhadian, C.E., eds. 2014. The Oxford Handbook of Religious Conversion. Oxford: Oxford University Press.

Richardson, J.T., and van der Lans, J., and Franz Derks, F., 1986. "Leaving and Labeling: Voluntary and Coerced Disaffiliation from Religious Social Movements." Research in Social Movements. 9, 97-126.

Stolz, J. et al. 2016. (Un)believing in Modern Society: Religion, Spirituality, and Religioussecular Competition. Abingdon: Routledge.

Streib, H., Hood, R.W., Keller, B., Csöff R-M., and Silver, C.F. 20og. Deconversion: Qualitative and Quantitative Results from Cross-cultural Research in Germany and the United States of America. Göttingen: Vandenhoeck and Ruprecht.

Toft, M.D., Philpott, D., and Shah, T.S. 2011. God's Century: Resurgent Religion and Global Politics. New York: W.W. Norton.

Wright, S.A. 2014. "Disengagement and Apostasy in New Religious Movements." In L.R. Rambo and C.E. Farhadian, eds, The Oxford Handbook of Religious Conversion. Oxford: Oxford University Press, 706-735.

Wright, S.A. and Ebaugh, H.R. 1993. "Leaving New Religions." In D.G. Bromley and J.K. Hadden, eds, Religion and the Social Order: The Handbook of Cults and Sects in America, Vol. 3 (Part B). Greenwich, Connecticut, 117-138.

Zuckerman, P. 2012. Faith No More: Why People Reject Religion. Oxford and New York: Oxford University Press. 